Zeszyty Naukowe Szkoły Głównej Gospodarstwa Wiejskiego w Warszawie Problemy Rolnictwa Światowego tom 17 (XXXII), zeszyt 3, 2017: 177-186

DOI: 10.22630/PRS.2017.17.3.64

Sylwia Kierczyńska ${ }^{1}$

Uniwersytet Przyrodniczy w Poznaniu

\title{
Podaż wiśni na rynku międzynarodowym a ceny skupu wiśni do przetwórstwa w Polsce
}

\section{Sour Cherry Supply in the International Market and the Prices of Sour Cherry for Processing in Poland}

\begin{abstract}
Synopsis. Celem pracy było zbadanie związku czynników podażowych na rynku wiśni z cenami skupu wiśni do przetwórstwa w Polsce. Analizę związku pomiędzy cenami skupu wiśni a wielkością produkcji wiśni w poszczególnych krajach oraz poziomem eksportu wiśni przeprowadzono przy wykorzystaniu współczynników korelacji Pearsona oraz Spearmana. Wielkość produkcji wiśni w krajach, będących ich największymi producentami i eksporterami (Węgry, Serbia Polska) była ujemnie skorelowana z cenami skupu wiśni do przetwórstwa w Polsce. Wielkość produkcji wiśni w krajach będących ich importerami (Niemcy, USA) była również ujemnie skorelowana z cenami skupu wiśni w Polsce. Związek pomiędzy wielkością eksportu wiśni z Węgier, Serbii i Polski a cenami skupu wiśni w Polsce był słaby i nieistotny statystycznie. Korelacja pomiędzy wielkością eksportu wiśni z tych krajów a cenami skupu wiśni w Polsce była ujemna.
\end{abstract}

Słowa kluczowe: produkcja wiśni, eksport wiśni, przetwórstwo wiśni, ceny wiśni do mrożenia, ceny wiśni do tłoczenia

\begin{abstract}
The aim of the study was to examine the relation between the supply-side factors and the prices of sour cherries for processing in Poland. Analysis of the relation between prices of sour cherries for processing in Poland and the amount of cherry production and export in selected countries was carried out using the correlation coefficients of Pearson and Spearman's. The production of sour cherries in the countries - largest producers and exporters (Hungary, Serbia, Poland) was negatively correlated with the prices of sour cherries for processing in Poland. The production of sour cherries in the countries-importers (Germany, USA) was also negatively correlated with the prices for sour cherry. The relation between the amount of sour cherries export from Hungary, Serbia and Poland and prices for sour cherries in Poland was weak and statistically non-significant. Export volume was negatively correlated with the prices for sour cherries in Poland.
\end{abstract}

Key words: sour cherry production, sour cherry export, sour cherry processing, the cherry price for freezing, the cherry price for stamping

\section{Wprowadzenie}

W światowej produkcji owoców Polska jest znaczącym producentem wiśni, porzeczek, truskawek, malin, agrestu oraz borówki. Według danych Faostat ${ }^{2}$, do największych europejskich producentów wiśni, oprócz Polski należą: Rosja, Ukraina, a także Turcja. Relatywnie wysokie zbiory wiśni są również na Węgrzech i w Serbii, która ma sprzyjające

\footnotetext{
${ }^{1}$ dr inż., Katedra Ekonomiki Przedsiębiorstw Agrobiznesu, Wydział Ekonomiczno-Społeczny, UP w Poznaniu, ul. Wojska Polskiego 28, 60-637 Poznań, e-mail: kierczynska@up.poznan.pl

${ }^{2}$ www.faostat.org.
} 
warunki do uprawy tych owoców (Bulatović i in., 2013) i jest liczącym się na rynku międzynarodowym producentem wiśni (Nosecka i in., 2012, s. 72).

Wiśnia jest gatunkiem dziko rosnącym $\mathrm{w}$ warunkach klimatu umiarkowanego, a pochodzi z Kaukazu i południowo-wschodniej Europy. Uprawa wiśni w Polsce ma swoją tradycję, sięgającą Średniowiecza. Pierwsze drzewka sadzono wtedy przy klasztorach, w ogrodach przydomowych zaczęto ją uprawiać w XVIII wieku, a towarowe sady wiśniowe zaczęto zakładać w latach 30-tych ubiegłego wieku (Makosz, 2006).

Produkcja wiśni w Polsce rozwijała się dzięki zapotrzebowaniu ze strony przetwórstwa owocowo-warzywnego. Jak podaje GUS (2013, s. 15), ponad 70\% zbiorów tych owoców w Polsce przeznaczano na przemysł. Przetwórstwo wiśni jest prowadzone w celu otrzymania głównie dwóch produktów - zagęszczonego soku wiśniowego oraz mrożonek, w związku $\mathrm{z}$ tym od producentów pozyskiwane są wiśnie jako surowiec $\mathrm{w}$ dwóch klasach jakościowych - wiśnie do tłoczenia, jako surowiec do produkcji soków, oraz wiśnie do mrożenia, surowiec wyższej klasy jakościowej do produkcji mrożonek. Mniejsze znaczenie na rynku polskim mają obecnie kompoty $\mathrm{z}$ wiśni. W przetwórstwie wiśni w Polsce dominują mrożonki i ten produkt przemysłu przetwórczego przeznaczany jest głównie na eksport (Nosecka, red. 2014, s. 10). Polska jest liczącym się w świecie i czołowym na rynkach Unii Europejskiej producentem i eksporterem mrożonek $\mathrm{z}$ wiśni.

Przemysł owocowo-warzywny rozwija się w Polsce między innymi dzięki dostępności obfitej bazy surowcowej. Podaż wiśni w Polsce uzależniona jest w dużym stopniu od warunków przyrodniczych, a konkretnie - od pogody w czasie zimy oraz w okresie kwitnienia i zawiązywania owoców, ale także w czasie dojrzewania i zbiorów owoców. Silne mrozy w okresie zimowym mogą przyczynić się do przemarzania drzew i spowodować obniżenie potencjału produkcyjnego sadów wiśniowych na kilka lat. Podobnie - duża wrażliwość drzew wiśni na choroby kory i drewna, i zaniechanie przez sadowników ochrony przed tymi patogenami może być przyczyną gorszego plonowania oraz zamierania drzew (Makosz 2010). Natomiast przymrozki w okresie kwitnienia i związywania owoców mogą być przyczyną niskich zbiorów w danym roku i w sprzyjających warunkach - wysokich w roku kolejnym.

Zbiory wiśni uzależnione są od nieprzewidywalnych warunków przyrodniczych, co jest przyczyną trudności w szacowaniu wielkości zbiorów oraz jedną z przyczyn zmienności cen skupu wiśni do przetwórstwa w Polsce. Duża zmienność cen skupu wiśni oraz pojawiające się co jakiś czas problemy ze zbyt niską opłacalnością produkcji wiśni, spowodowaną niskimi cenami (Klimek, 2012) sprawiają, iż pojawia się pytanie o przyczyny kształtowania się cen skupu wiśni. Dotychczas prowadzone były badania na temat związku cen skupu wiśni z wielkością zbiorów tych owoców. Jak podaje Kierczyńska (2011) oraz Sobczak (2015), poziom cen skupu wiśni do mrożenia był istotnie ujemnie skorelowany z wielkością zbiorów w danym roku.

Jednakże, plonowanie drzew wiśni w Polsce i związana z tym wielkość zbiorów nie jest jedynym czynnikiem mającym znaczenie $\mathrm{w}$ kształtowaniu się cen skupu wiśni do przetwórstwa. Jak podaje Ś wietlik (2003), ,,ceny skupu wiśni w 2002 roku były dość wysokie na skutek niskich zbiorów na Węgrzech, w Serbii i w USA. W USA zebrano o $60 \%$ mniej wiśni niż w 2001 roku, importowano więc więcej polskich wiśni mrożonych". Podobnie było w 2012 roku, w którym na skutek silnych mrozów odnotowano duże straty w uprawach wiśni w Stanie Michigan, głównym regionie uprawy wiśni w USA, co przełożyło się na wzrost popytu na mrożone wiśnie z Polski i z Serbii (Możliwy..., 2012, Zbiory..., 2013). Także w 2016 roku, spadek cen skupu wiśni w Polsce spowodowany był sytuacją podażową w kraju 
(wysokie zbiory wiśni), dobrymi zbiorami w Serbii, Turcji i na Węgrzech oraz wysokimi zapasami mrożonych wiśni na początku sezonu (Gwara 2016). Zatem, zbiory w innych krajach, produkujących wiśnie na dużą skalę i eksportujących przetwory z wiśni (mrożonki, sok zagęszczony) oraz zapotrzebowanie na zagranicznych rynkach zbytu na przetwory z wiśni mogą być także czynnikami wpływającymi na ceny skupu wiśni do przetwórstwa w Polsce.

W literaturze nie ma badań weryfikujących doniesienia dotyczące przyczyn kształtowania się cen skupu wiśni. Celem niniejszej pracy było zbadanie związku sugerowanych $\mathrm{w}$ doniesieniach literaturowych czynników podażowych na rynku wiśni z cenami skupu wiśni do przetwórstwa w Polsce. Do czynników stojących po stronie podaży zaliczono: wielkość produkcji wiśni w krajach będących ich głównymi producentami, wielkość produkcji wiśni w krajach, będących głównymi odbiorcami wiśni z Polski, wielkość eksportu wiśni w krajach będących ich głównymi eksporterami.

Związek wymienionych czynników z cenami skupu wiśni do przetwórstwa w Polsce określono przy wykorzystaniu współczynników korelacji.

\section{Dane i metody badań}

Aby zrealizować cel pracy przeprowadzono analizę związku pomiędzy określonymi wyżej czynnikami a cenami skupu wiśni do przetwórstwa w Polsce. Ceny skupu wiśni przyjęto $\mathrm{w}$ trzech wariantach: średnie ceny skupu podawane przez $\mathrm{GUS}^{3}$ oraz ceny skupu wiśni do tłoczenia i ceny skupu wiśni do mrożenia, publikowane przez IERiGŻ-PIB w raportach rynkowych „Rynek owoców i warzyw”. Dane na temat wielkości zbiorów wiśni w poszczególnych krajach oraz poziomu eksportu pozyskano z bazy danych Faostat. Zakres czasowy analizy to lata 1993 - 2014, podzielony na dwa podokresy: 1993-2003 i 2004-2014. Ze względu na dostępność danych na temat cen skupu wiśni do mrożenia oraz wiśni do tłoczenia, analizy dotyczące związku cen skupu wiśni do mrożenia i cen skupu wiśni do tłoczenia obejmują okres 1997-2014 oraz dwa podokresy: 1997-2003 i 2004-2014. Ponadto, w bazie Faostat dane na temat eksportu oraz importu wiśni dostępne były tylko do 2013 roku.

Analizę związku pomiędzy cenami skupu wiśni a wielkością produkcji wiśni oraz poziomem eksportu w poszczególnych krajach przeprowadzono przy wykorzystaniu współczynników korelacji Pearsona oraz Spearmana (dla zmiennych nieposiadających rozkładu normalnego).

\section{Wyniki badań}

\section{Międzynarodowy rynek wiśni}

Produkcja wiśni na świecie w analizowanym okresie 1993-2014 wynosiła rocznie średnio 1159 tys. ton i zwiększyła się o 17\% z 1069 tys. ton w latach 1993-2003 do 1248 tys. ton w okresie 2004-2014 (tab. 1). Największy udział w produkcji wiśni miała Rosja (rys. 1), której zbiory (177 tys. ton) stanowiły 15\% światowej produkcji tych owoców. Zbiory w Rosji zwiększyły się o 21\% ze 160 tys. ton średnio w latach 1993-2003 do 194 tys. ton w okresie

${ }^{3}$ Ceny skupu GUS z poszczególnych lat. 


\section{S. Kierczyńska}

2004-2014. Drugim spośród największych producentów wiśni na świecie była Polska z 14\% udziałem $\mathrm{w}$ produkcji światowej. W Polsce zbierano przeciętnie 162 tys. ton wiśni, a produkcja w analizowanym okresie zwiększyła się o $13 \%$ - z 153 tys. ton średnio w latach 1993-2003 do 173 tys. ton w latach 2004-2014. Produkcja wiśni zwiększała się również na Ukrainie i w Turcji. Zbiory wiśni na Ukrainie wzrosły o 11\% (ze 141 tys. ton do 156 tys. ton), natomiast w Turcji wzrosły aż o $58 \%$ (ze 108 tys. ton do 171 tys. ton). Zmniejszyły się natomiast o $13 \%$ - ze 127 tys. ton do 110 tys. ton zbiory wiśni w USA. Również duży (o 75\%) spadek produkcji wiśni miał miejsce w Niemczech, gdzie zbiory zmniejszyły się z 91 tys. ton średnio w latach 1993-2003 do 23 tys. ton w okresie 2004-2014. Wzrosły natomiast zbiory wiśni w Serbii, Iranie i na Węgrzech odpowiednio o 34\%, 118\% i 15\%.

Tabela 1. Średnia produkcja wiśni w poszczególnych krajach (w tys. ton) w latach 1993-2014

Table 1. Average sour cherry production (in thous. tons) in the years 1993-2014

\begin{tabular}{l|ccccccc}
\hline \multirow{1}{*}{ Kraj } & $\begin{array}{c}\text { Produkcja } \\
\text { wiśni w } \\
\text { latach } \\
1993-2014\end{array}$ & $\begin{array}{c}\text { Produkcja } \\
\text { wiśni w } \\
\text { latach } \\
1993-2003\end{array}$ & $\begin{array}{c}\text { Produkcja } \\
\text { wiśni w } \\
\text { latach } \\
2004- \\
2014\end{array}$ & $\begin{array}{c}\text { Zmiany } \\
2004- \\
2014 / 1993- \\
2003\end{array}$ & $\begin{array}{c}\text { Współczynnik } \\
\text { zmienności } \\
1993-2003\end{array}$ & $\begin{array}{c}\text { Współczynnik } \\
\text { zmienności } \\
2004-2014\end{array}$ & $\begin{array}{c}\text { Współczynnik } \\
\text { zmienności } \\
1993-2014\end{array}$ \\
\hline Rosja & 177 & 160 & 195 & 1,21 & $20 \%$ & $17 \%$ & $21 \%$ \\
Polska & 163 & 153 & 173 & 1,13 & $13 \%$ & $16 \%$ & $16 \%$ \\
Ukraina & 149 & 141 & 156 & 1,11 & $24 \%$ & $20 \%$ & $23 \%$ \\
Turcja & 140 & 108 & 171 & 1,58 & $15 \%$ & $14 \%$ & $27 \%$ \\
USA & 119 & 127 & 110 & 0,87 & $29 \%$ & $28 \%$ & $30 \%$ \\
Serbia & 83 & 72 & 95 & 1,34 & $20 \%$ & $23 \%$ & $23 \%$ \\
Iran & 66 & 41 & 90 & 2,18 & $18 \%$ & $29 \%$ & $47 \%$ \\
Węgry & 60 & 56 & 64 & 1,15 & $21 \%$ & $22 \%$ & $23 \%$ \\
Niemcy & 57 & 91 & 23 & 0,25 & $36 \%$ & $38 \%$ & $74 \%$ \\
Ogółem & 1159 & 1069 & 1248 & 1,17 & $11 \%$ & $8 \%$ & $8 \%$ \\
\hline
\end{tabular}

Źródło: opracowanie własne na podstawie danych FAOSTAT.

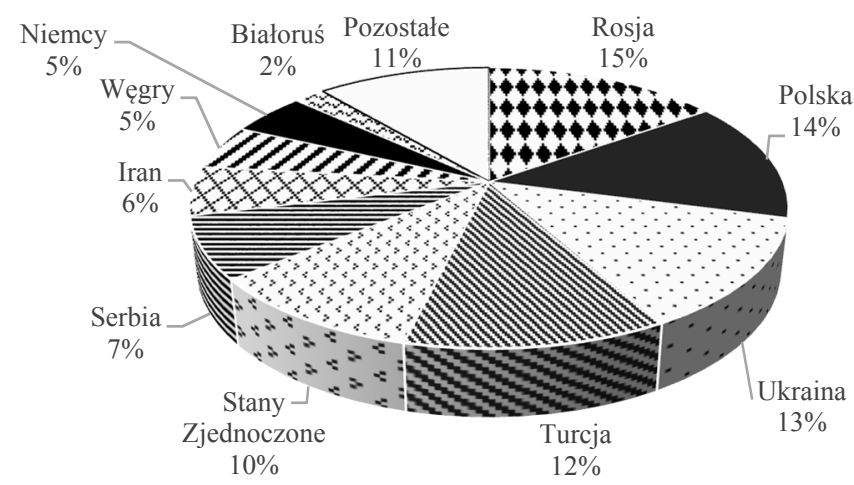

Rys. 1. Udział poszczególnych krajów w produkcji wiśni na świecie średnio w latach 1993-2014

Fig. 1. Share of average sour cherry production per country in the years 1993-2014

Źródło: opracowanie własne na podstawie danych Faostat. 
$\mathrm{Na}$ rynku międzynarodowym, najwięcej wiśni eksportowały Węgry (tab. 2). W analizowanym okresie 1993-2013 było to średnio 17,2 tys. ton rocznie i wielkość ta nie zmieniła się znacząco (1\%), a współczynnik zmienności wskazuje na nieduże odchylenia wartości od średniej zarówno dla całego przedziału czasowego, jak i w badanych podokresach. Znaczącym eksporterem wiśni była również Polska, skąd eksportowano przeciętnie 7,8 tys. ton wiśni rocznie. Wielkość eksportu w poszczególnych podokresach nie zmieniła się znacząco - dane statystyczne wskazują na $2 \%$ spadek wielkości eksportu w latach 2004-2013 w porównaniu do okresu 1993-2003, jednakże współczynniki zmienności wskazują na duże wahania w latach 1993-2003, co było spowodowane, jak wskazują na to dane zamieszczone w bazie Faostat, brakiem eksportu w latach 2001-2003. Kolejnym spośród największych eksporterów wiśni na rynku międzynarodowym była Serbia, skąd wysyłano w latach 1993-2013 średnio 4,6 tys. ton wiśni rocznie, a wielkość eksportu zwiększyła się o 121\% - ze średnio 2,7 tys. ton rocznie w latach 1993-2003 do 6,1 tys. ton w okresie 2004-2013. Współczynnik zmienności wskazuje na duże odchylenia wielkości eksportu wiśni z Serbii w poszczególnych latach od średnich dla badanych podokresów. W Hiszpanii i w Austrii eksport wiśni był relatywnie nieduży i wynosił przeciętnie nieco ponad tysiąc ton rocznie, z tym, że w Hiszpanii można zauważyć duży, bo ponad czterokrotny wzrost eksportu wiśni w latach 2004-2013 w odniesieniu do okresu 19932003, natomiast w Austrii wielkość eksportu wiśni była równomierna w analizowanych podokresach, chociaż na podstawie współczynnika zmienności można wnioskować i dużych wahaniach w poszczególnych latach badanych podokresów.

Tabela 2. Eksport i import wiśni na rynku międzynarodowym (w tys. ton) w latach 1993-2013

Table 2. Sour cherry export and import in the international market (in thous. tons) in the years 1993-2013

\begin{tabular}{|c|c|c|c|c|c|c|c|}
\hline Kraj & $\begin{array}{c}\text { W latach } \\
1993- \\
2013\end{array}$ & $\begin{array}{c}\text { W latach } \\
1993-2003\end{array}$ & $\begin{array}{c}\text { W latach } \\
2004- \\
2013\end{array}$ & $\begin{array}{c}\text { Zmiany } \\
\text { 2004- } \\
2013 / 1993- \\
2003\end{array}$ & $\begin{array}{l}\text { Współczynnik } \\
\text { zmienności } \\
\text { 1993-2003 }\end{array}$ & $\begin{array}{l}\text { Współczynnik } \\
\text { zmienności } \\
\text { 2004-2013 }\end{array}$ & $\begin{array}{c}\text { Współczynnik } \\
\text { zmienności } \\
\text { 1993-2013 }\end{array}$ \\
\hline \multicolumn{8}{|c|}{ Eksport } \\
\hline Węgry & 17,2 & 17,0 & 17,4 & 1,01 & $33 \%$ & $26 \%$ & $30 \%$ \\
\hline Polska & 7,8 & 7,9 & 7,8 & 0,98 & $90 \%$ & $45 \%$ & $73 \%$ \\
\hline Serbia* & 4,6 & 2,7 & 6,1 & 2,21 & $91 \%$ & $85 \%$ & $98 \%$ \\
\hline Hiszpania & 1,3 & 0,5 & 2,1 & 4,05 & $79 \%$ & $51 \%$ & $88 \%$ \\
\hline Austria & 1,2 & 1,2 & 1,1 & 0,93 & $92 \%$ & $98 \%$ & $95 \%$ \\
\hline \multicolumn{8}{|c|}{ Import } \\
\hline Niemcy & 24,9 & 27,2 & 22,4 & 0,82 & $20 \%$ & $26 \%$ & $24 \%$ \\
\hline Rosja** & 5,6 & - & 5,6 & - & - & $54 \%$ & $54 \%$ \\
\hline Austria & 3,6 & 4,1 & 3,1 & 0,75 & $44 \%$ & $56 \%$ & $51 \%$ \\
\hline Belgia & 2,7 & 2,9 & 2,4 & 0,81 & $26 \%$ & $44 \%$ & $36 \%$ \\
\hline Węgry & 0,7 & 0,3 & 1,1 & 3,38 & $110 \%$ & $88 \%$ & $117 \%$ \\
\hline USA & 0,3 & 0,2 & 0,4 & 1,67 & $154 \%$ & $175 \%$ & $176 \%$ \\
\hline
\end{tabular}

* dane dla Serbii dostępne od 1996 roku, ** dane dla Rosji dostępne od 2004 roku.

Źródło: opracowanie własne na podstawie danych FAOSTAT. 


\section{S. Kierczyńska}

Do największych importerów wiśni na rynku międzynarodowym należały Niemcy, a wielkość importu wiśni wynosiła średnio prawie 25 tys. ton rocznie w latach 1993-2013 (tab. 2). Import wiśni w Niemczech był dość stabilny, chociaż zmniejszył się o $18 \%$ w okresie 2004-2013 w porównaniu do lat 1993-2003. Współczynnik zmienności wskazuje jednak na nieduże odchylenia danych $\mathrm{z}$ poszczególnych lat $\mathrm{w}$ stosunku do średnich $\mathrm{z}$ analizowanych podokresów. Dużym importerem wiśni była także Rosja. Dane dostępne w bazie Faostat od 2004 roku wskazują, iż kraj ten importował średnio 5,6 tys. ton wiśni rocznie. Natomiast w Austrii importowano średnio 3,6 tys. ton wiśni rocznie i wielkość importu zmniejszyła się w badanych podokresach o $25 \%$ - z 4,1 tys. ton w latach 1993-2003 do 3,1 tys. ton w okresie 2004-2013. Również w Belgii, gdzie sprowadzano średnio 2,7 tys. ton wiśni, import wiśni zmniejszył się w analizowanym okresie z 2,9 tys. ton do 2,4 tys. ton. Dane statystyczne wskazują natomiast na rosnący import wiśni na Węgrzech, które są jednocześnie największym eksporterem tego gatunku owoców. Import wiśni przez Węgry zwiększył się ponad trzykrotnie w analizowanym okresie - z 0,3 tys. ton średnio w latach 1993-2003 do 1,1 tys. ton $\mathrm{w}$ okresie 2004-2013. Stany Zjednoczone natomiast importowały w analizowanych latach stosunkowo niewiele wiśni - średnio było to 0,3 tys. ton rocznie. Współczynnik zmienności wskazuje na duże odchylenia danych z poszczególnych lat od średniej dla danego okresu i jeśli w latach 1993-2003 importowano średnio 0,2 tys. ton rocznie, to wielkości te wahały się od 2 ton w roku 1993 do 1233 ton w roku 2002, natomiast w okresie 2004-2013 Faostat podaje zerowy import w latach 2006-2011, natomiast w latach 2012 zaimportowano 2006 ton wiśni oraz 1734 tony w 2013 roku. Według doniesień literaturowych (Świetlik, 2003; Możliwy..., 2012; Zbiory...; 2013), zwiększony import wiśni w Stanach Zjednoczonych w latach 2002 i 2012-2013 był spowodowany niskimi zbiorami wiśni na skutek niesprzyjających warunków atmosferycznych (duże przymrozki) w Stanie Michigan, w którym głównie odbywa się produkcja wiśni w USA.

\section{Ceny skupu wiśni w Polsce}

Ceny skupu wiśni, publikowane przez GUS, w latach 1993-2014 wahały się od 0,22 zł $/ \mathrm{kg} \mathrm{w} 1993$ roku do 3,43 zł/kg w 2012 roku (ryc.2), średnio było to $1,7 \mathrm{zł} / \mathrm{kg}$. Średnia cena skupu wiśni w okresie 1993-2003 wynosiła 1,53 zł/kg i była o $23 \%$ niższa niż średnia dla kolejnego podokresu 2004-2014, która wynosiła 1,88 zł/kg. Zmienność cen skupu wiśni, zarówno w całym badanym okresie jak i w wyróżnionych podokresach była podobna i wynosiła nieco ponad czterdzieści procent. 


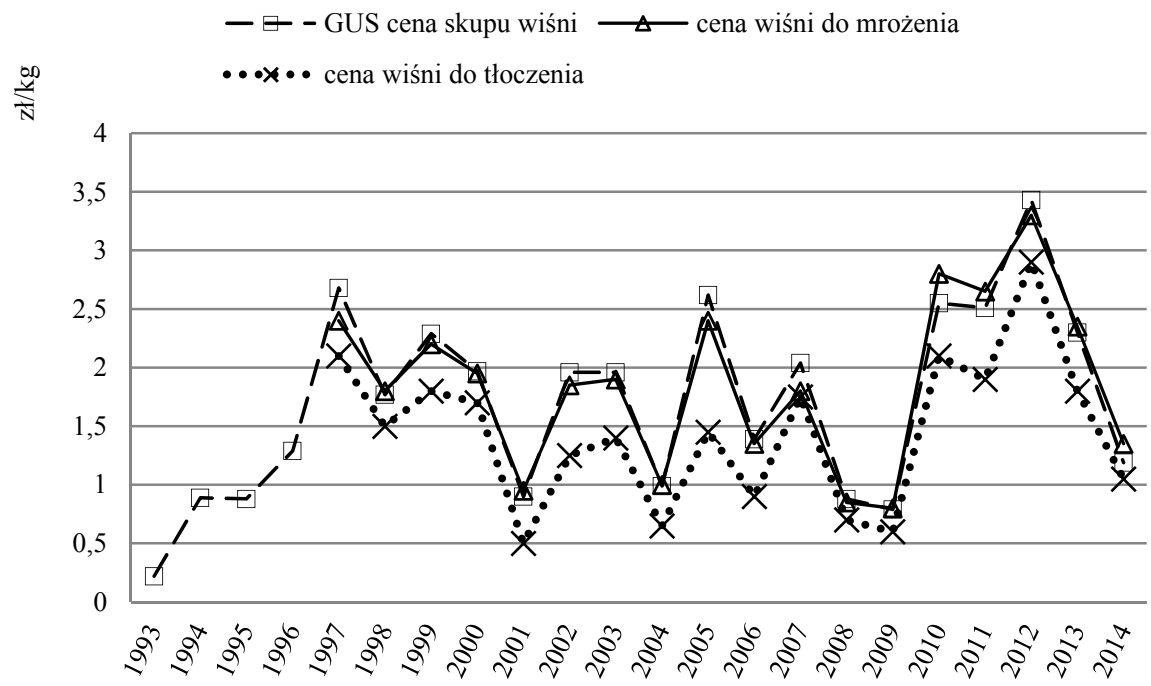

Rys. 2. Ceny skupu wiśni w Polsce w latach 1993-2014

Fig. 2. Prices of sour cherry for processing in Poland in the 1993-2014

Źródło: opracowanie własne na podstawie danych: FAOSTAT oraz IERiGŻ-PIB.

Średnie ceny skupu wiśni, publikowane przez GUS, obrazują ceną będącą średnią ceną skupu w przetwórstwie jak i na rynku detalicznym (jednakże należy pamiętać, iż większość wiśni trafiała do przetwórstwa). Publikowane przez IERiGŻ ceny skupu wiśni dotyczą tylko owoców przeznaczonych do przetwórni i są określane dla dwóch klas jakościowych: wiśni do mrożenia oraz wiśni do tłoczenia. W analizowanym okresie ceny wiśni do mrożenia były zbliżone do średnich cen skupu publikowanych przez GUS. Wahały się od 0,8 zł/kg w 2009 roku do $3,3 \mathrm{zz} / \mathrm{kg} \mathrm{w} 2012$ roku, średnio było to $1,87 \mathrm{zl} / \mathrm{kg} \mathrm{w}$ całym badanym okresie (ceny publikowane od 1997 roku). W analizowanych podokresach średnie ceny skupu wiśni do mrożenia prawie nie różniły się od siebie i wynosiły odpowiednio 1,86 zł/kg w latach 1997 2003 oraz 1,88 zł/kg w latach 2004-2014. Ceny wiśni do mrożenia charakteryzowały się mniejszą zmiennością niż średnie ceny skupu publikowane przez GUS. Natomiast średnia cena wiśni do tłoczenia była o $23 \%$ niższa niż średnia cena wiśni do mrożenia i wynosiła $1,45 \mathrm{zł} / \mathrm{kg}$. Średnie ceny dla wydzielonych podokresów nie różniły się prawie i wynosiły odpowiednio 1,46 zł/ kg w latach 1997-2003 oraz 1,44 zł/kg w latach 2004-2014. Zmienność cen wiśni do tłoczenia $\mathrm{w}$ analizowanych przedziałach czasowych była jednak większa niż zmienność cen wiśni do mrożenia. 


\section{Obecność wiśni na rynku międzynarodowym a ceny skupu wiśni do przetwórstwa w Polsce}

Wyniki niniejszych badań wskazują na ujemną korelację pomiędzy zbiorami wiśni w krajach, które są liczącymi się na arenie międzynarodowej producentami (i eksporterami) wiśni, czyli w Polsce, na Węgrzech i w Serbii, a cenami skupu wiśni do przetwórstwa w Polsce (tab. 3). Oznacza to, iż w latach, w których zbiory wiśni w tych krajach były wysokie, ceny skupu wiśni w Polsce były relatywnie niskie. Ujemna była również korelacja pomiędzy wielkością produkcji wiśni w Niemczech i USA, a cenami skupu wiśni w Polsce.

Można zauważyć wysoką korelację pomiędzy produkcją wiśni na Węgrzech, w USA oraz w Niemczech, a cenami skupu wiśni w Polsce. Produkcja wiśni w Niemczech już od wielu lat była ograniczana (karczowano sady i nie zakładano nowych) ze względu na rosnące koszty siły roboczej (wynikające z pracochłonnego zbioru) i związane z tym rosnące koszty produkcji wiśni oraz zwiększającą się konkurencję węgierską i polską na rynku wiśni (Zmarlicki, 2004; Makosz, 2006; Schwartau, 2010). Niemcy jednak nadal produkują wiśnie i wysokie zbiory $\mathrm{w}$ tym kraju powodują zmniejszenie popytu na wiśnie $\mathrm{z}$ zagranicy. Jednocześnie Niemcy stanowią obecnie główny rynek zbytu dla wiśni zarówno z Polski, jak i z Węgier i Serbii (Hungarian..., 2017). Wzrost produkcji wiśni w krajach konkurencyjnych dla Polski oznacza wzrost podaży wiśni na rynku międzynarodowym i w ten sposób przyczynia się do spadku cen skupu wiśni do przetwórstwa w Polsce. Inaczej przedstawia się sytuacja w przypadku Stanów Zjednoczonych. Kraj ten produkuje relatywnie dużo wiśni na własne potrzeby i tylko w latach niedoborów na własnym rynku, spowodowanych niekorzystnymi warunkami atmosferycznymi, poszukuje surowca na rynku międzynarodowym. Wskazują na to dane Faostatu na temat importu wiśni przez USA, który przeciętnie był relatywnie niewielki, jednak charakteryzował się dużymi odchyleniami od średniej (tab.2). Spodziewane duże zapotrzebowanie na wiśnie z importu w USA (np. w 2012 r.) było impulsem dla przetwórstwa do pozyskania odpowiednio dużej ilości surowca, co generowało zwiększony popyt na rynku wiśni do przetwórstwa w Polsce i co za tym idzie, wysoką cenę skupu. Niniejsze badania wskazują na wysoką i istotną korelację pomiędzy cenami skupu wiśni do przetwórstwa w Polsce a zbiorami wiśni w USA głównie w okresie 2004-2014, na co wpływ miała wspomniana już sytuacja związana z niekorzystnymi warunkami atmosferycznymi w Stanie Michigan w latach 2012 i 2013.

Wyniki badań wskazują natomiast na słabą korelację pomiędzy wielkością produkcji wiśni w Serbii a cenami skupu wiśni w Polsce sugerując, iż cena skupu wiśni w Polsce była niezbyt silnie związana z wielkością zbiorów wiśni w Serbii. Położenie Serbii na południu Europy sprawia, iż miała ona inne rynki zbytu wiśni niż położona na północy Polska i konkurencja Serbii nie była tak istotna dla Polski jak konkurencja ze strony Węgier. Według danych zawartych w bazie Faostat, Serbia eksportowała wiśnie, poza Niemcami, także do krajów południowej Europy, natomiast rynkami zbytu wiśni dla Węgier i Polski były te same kraje Unii Europejskiej. Przemiany polityczne w Serbii, która wyłoniła się z federacji Republik byłej Jugosławii w 2003 roku, niewątpliwie oddziaływały na działalność gospodarczą w tym kraju oraz na produkcję wiśni. W związku z tym, spójne dane statystyczne dostępne są dla Serbii od roku 2004 i tym można wyjaśnić dodatni i nikły związek pomiędzy produkcją wiśni w Serbii a cenami skupu wiśni w Polsce w latach 19932003. 
Największymi eksporterami wiśni na rynku międzynarodowym były Węgry, Polska i Serbia. Eksport wiśni (świeżych, schłodzonych) z Węgier stanowił około 30\% wielkości produkcji, a w przypadku Polski i Serbii było to około 5\% zbiorów.

Tabela 3. Korelacje pomiędzy wielkością produkcji wiśni i eksportem a ceną skupu wiśni do przetwórstwa w Polsce w latach 1993-2014

Table 3. Correlation between sour cherry production, export and the sour cherry price in Poland in the 1993-2014

\begin{tabular}{|c|c|c|c|c|c|c|c|c|c|}
\hline \multirow{2}{*}{ Kraj } & \multicolumn{3}{|c|}{ cena GUS } & \multicolumn{3}{|c|}{ cena wiśni do mrożenia } & \multicolumn{3}{|c|}{ Cena wiśni do tłoczenia } \\
\hline & $\begin{array}{c}1993- \\
2014 * * *\end{array}$ & $\begin{array}{l}1993- \\
2003\end{array}$ & $\begin{array}{c}2004- \\
2014 * * *\end{array}$ & $\begin{array}{c}1997- \\
2014 * * *\end{array}$ & $\begin{array}{l}1997- \\
2003\end{array}$ & $\begin{array}{c}2004- \\
2014 * * *\end{array}$ & $\begin{array}{c}1997- \\
2014 * * *\end{array}$ & $\begin{array}{l}1997- \\
2003\end{array}$ & $\begin{array}{c}2004- \\
2014 * * *\end{array}$ \\
\hline \multicolumn{10}{|c|}{ Produkcja } \\
\hline Węgry & $-0,4997 *$ & $-0,5249 * *$ & $-0,6735^{*}$ & $-0,4279 * *$ & 0,0250 & $-0,6036^{*}$ & $-0,3967$ & 0,1561 & $-0,6176 * *$ \\
\hline Serbia & $-0,1492$ & $-0,4643$ & $-0,1585$ & $-0,2036$ & 0,0648 & $-0,1565$ & $-0,0764$ & 0,0608 & $-0,0260$ \\
\hline Polska & $-0,1619$ & 0,0845 & $-0,4933$ & $-0,4462 * *$ & $-0,6225$ & $-0,4286$ & $-0,5166^{*}$ & $-0,7494 * *$ & $-0,4577$ \\
\hline USA & $-0,5351^{*}$ & $-0,4474$ & $-0,5557 * *$ & $-0,4075 * *$ & $-0,1149$ & $-0,5546 * *$ & $-0,3669$ & 0,0944 & $-0,6329 *$ \\
\hline Niemcy & $-0,4650^{*}$ & $-0,7626^{*}$ & $-0,5497 * *$ & $-0,2543$ & $-0,5405$ & $-0,5781 * *$ & $-0,2634$ & $-0,5789$ & $-0,6168^{*}$ \\
\hline \multicolumn{10}{|c|}{ Eksport } \\
\hline Węgry & 0,1802 & 0,6099 & $-0,3138$ & $-0,1715$ & $-0,0733$ & $-0,1884$ & $-0,1220$ & 0,0583 & $-0,1793$ \\
\hline Serbia & $-0,0156$ & $-0,0709$ & $-0,0689$ & $-0,1469$ & $-0,1127$ & $-0,1450$ & $-0,1599$ & $-0,2493$ & $-0,0566$ \\
\hline Polska & $-0,0555$ & - & $-0,3682$ & 0,0050 & - & $-0,3420$ & 0,1489 & - & $-0,2090$ \\
\hline
\end{tabular}

$* \mathrm{p}<0,05, * * \mathrm{p}<0,1, * * *$ dla eksportu do $2013 \mathrm{r}$.

Źródło: opracowanie własne na podstawie danych: FAOSTAT oraz IERiGŻ-PIB.

Wyniki badań wskazują, iż eksport wiśni w latach 2004-2013 zarówno z Węgier, jak i z Serbii oraz Polski był ujemnie skorelowany z cenami skupu wiśni w Polsce co oznacza, że wysokiemu eksportowi towarzyszyły niskie ceny skupu w Polsce. Zbiory wiśni w Serbii i na Węgrzech rozpoczynają się zazwyczaj kilka tygodni wcześniej niż w Polsce (Makosz, 2008), dlatego wiśnie z tych krajów obecne są wcześniej na rynku międzynarodowym niż wiśnie z Polski. Mogą dzięki temu zaspokoić część popytu ze strony importerów i przyczynić się do obniżek cen na rynku, szczególnie w przypadku spodziewanych wysokich zbiorów wiśni.

Wyniki badań wskazują także, iż korelacja pomiędzy poziomem eksportu wiśni $\mathrm{z}$ analizowanych krajów, a cenami skupu tych owoców w Polsce jest słaba i nieistotna statystycznie, co oznacza, że podaż eksportowa wiśni na rynku międzynarodowym nie jest znaczącym czynnikiem w kształtowaniu cen skupu wiśni do przetwórstwa w Polsce. 


\section{S. Kierczyńska}

\section{Podsumowanie}

Wyniki niniejszych badań wskazują, iż wielkość produkcji wiśni w krajach, będących ich największymi producentami i eksporterami (Węgry, Serbia Polska) była ujemnie skorelowana $\mathrm{z}$ cenami skupu wiśni do przetwórstwa w Polsce, co oznacza, iż wysokiej produkcji wiśni w tych krajach towarzyszyły niskie ceny skupu wiśni w Polsce. Współczynniki korelacji w przypadku Węgier i Polski były wysokie i istotne statystycznie, co oznacza iż czynnik ten może być znaczący przy ustalaniu cen skupu wiśni do przetwórstwa w Polsce.

Wielkość produkcji wiśni w krajach będących ich importerami (Niemcy, USA) była ujemnie skorelowana z cenami skupu wiśni w Polsce, co oznacza, że niskim zbiorom wiśni w tych krajach towarzyszyły wysokie ceny skupu wiśni w Polsce. Współczynniki korelacji były wysokie i istotne statystycznie, co wskazuje na ważność tego czynnika dla określania poziomu cen skupu wiśni do przetwórstwa w Polsce.

Niewielka siła związku pomiędzy poziomem eksportu wiśni z Węgier, Serbii i Polski a cenami skupu wiśni w Polsce wskazuje na małe znaczenie tego czynnika w kształtowaniu cen skupu wiśni do przetwórstwa w Polsce.

\section{Literatura}

Bulatović, M.L., Rajić, Z., Dokowić, J., (2013). Development of fruit production and processing in the Republic of Serbia. Economics of Agriculture, 60(1), 141-151.

GUS (2013). Produkcja ogrodnicza. Badanie sadów w 2012 r. Główny Urząd Statystyczny, Departament Rolnictwa, Warszawa 2013

Gwara A. (2016). Analityk: Dobry sezon dla producentów truskawek, gorszy dla wiśni i porzeczek. Pobrane 9 listopada $2016 \mathrm{z}$ : http://www.sadyogrody.pl.

Hungarian fruit and vegetable sector: a summary. Pobrane 29 maj 2017 z: http://www.agroberichtenbuitenland.nl/polen/hungarian-fruit-and-vegetable-sector-a-summary/.

Kierczyńska, S. (2011). Wielkość produkcji a poziom cen wybranych gatunków owoców do przetwórstwa. Roczniki Naukowe SERiA, 12(2), 201-205.

Klimek, G. (2012). Rynek wiśni. Owoce Warzywa Kwiaty 6, 66-67.

Makosz, E. (2006). Wiśnie w Polsce. Sad Nowoczesny 7, 39-40.

Makosz, E.(2008). Wiśnie na świecie i w Polsce. Sad Nowoczesny 4, 50-51.

Makosz, E. (2010). Wstępna prognoza zbiorów owoców w Polsce. Hasło Ogrodnicze 7, 70.

Możliwy wzrost popytu na mrożone wiśnie europejskie ze strony USA. Bank BGZ, Pobrane 20 czerwca 2012 z: http://www.portalspozywczy.pl.

Nosecka, B. red. (2014). Sytuacja na światowym rynku wybranych przetworów owocowych i warzywnych. IERiGŻ-PIB, Warszawa 2014.

Nosecka, B., Bugała, A., Paszko, D., Zaremba, Ł., (2012). Sytuacja na światowym rynku wybranych produktów ogrodniczych i jej wpływ na polski rynek ogrodniczy. IERiGŻ-PIB, Warszawa 2012.

Schwartau, H. (2010). Załamanie na rynku wiśni. Sad Nowoczesny 5, 30-31.

Sobczak, W. (2015): Ceny wiśni na polskim rynku jako istotny czynnik decyzji producenta. Roczniki Naukowe SERiA, 17(5), 252-257.

Świetlik, J. (2003). Jak było na rynku owoców w zeszłym roku i jak będzie w tym. Sad Nowoczesny 5, 41-42.

Zbiory wiśni w USA pod znakiem zapytania. Bank BGŻ, Pobrane 3 lipca 2013 z: http://www.portalspozywczy.pl.

Zmarlicki, K. (2004). Koszty i opłacalność produkcji czereśni, śliwek i wiśni na Wspólnym Rynku. Sad Nowoczesny 8,31 . 